Provided for non-commercial research and education use. Not for reproduction, distribution or commercial use.

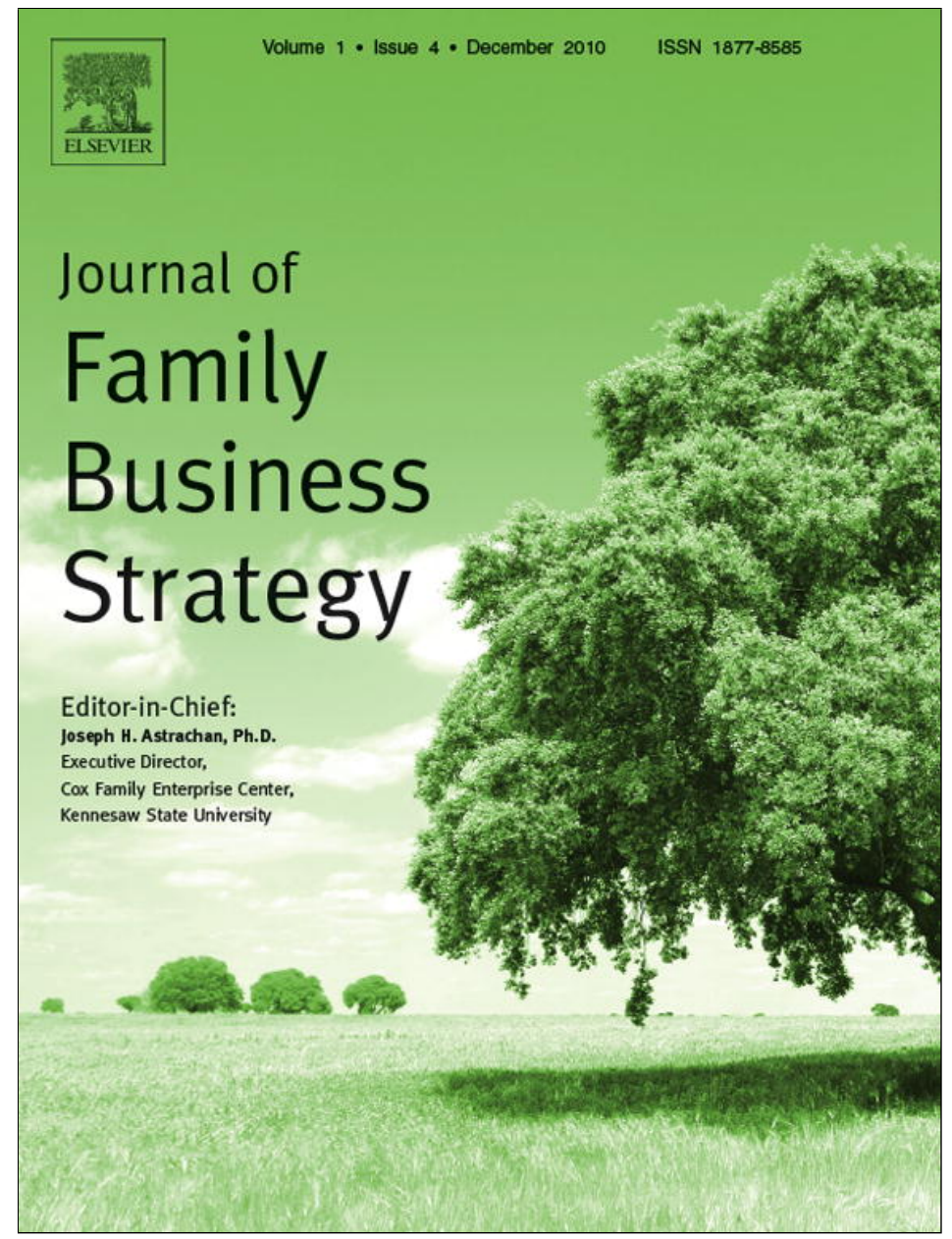

This article appeared in a journal published by Elsevier. The attached copy is furnished to the author for internal non-commercial research and education use, including for instruction at the authors institution and sharing with colleagues.

Other uses, including reproduction and distribution, or selling or licensing copies, or posting to personal, institutional or third party websites are prohibited.

In most cases authors are permitted to post their version of the article (e.g. in Word or Tex form) to their personal website or institutional repository. Authors requiring further information regarding Elsevier's archiving and manuscript policies are encouraged to visit:

http://www.elsevier.com/copyright 


\title{
The critical path to family firm success through entrepreneurial risk taking and image ${ }^{-i_{2}}$
}

\author{
Esra Memili ${ }^{\mathrm{a}, 1, *}$, Kimberly A. Eddleston ${ }^{\mathrm{b}, 2}$, Franz W. Kellermanns ${ }^{\mathrm{c}, \mathrm{d}, 3}$, \\ Thomas M. Zellweger ${ }^{\mathrm{e}, 4}$, Tim Barnett ${ }^{\mathrm{f}, 5}$
}

\author{
a Department of Management and Marketing, The Bryan School of Business and Economics, The University of North Carolina at Greensboro, \\ P.O. Box 26170, Greensboro, NC 27402-6170, United States \\ ${ }^{\mathrm{b}}$ Colege of Business Administration, Northeastern University, 319 Hayden Hall, Boston, MA 02115-5000, United States \\ ${ }^{\mathrm{c}}$ Department of Management, The University of Tennessee, Knoxville, TN 37996, United States \\ ${ }^{\mathrm{d}}$ INTES Center for Family Enterprises, WHU (Otto Beisheim School of Management), United States \\ ${ }^{\mathrm{e}}$ Center for Family Business, University of St. Gallen, Dufourstrasse 40a, CH-9000 St. Gallen, Switzerland \\ ${ }^{\mathrm{f}}$ College of Business and Industry, Mississippi State University, Box 9581, Mississippi State, MS 39762, United States
}

\section{A R T I C L E I N F O}

\section{Keywords:}

Family firms

Organizational identity

Risk taking

Image

\begin{abstract}
A B S T R A C T
Drawing from organizational identity theory, we explore how family ownership and family expectations influence family firm image and entrepreneurial risk taking, and ultimately firm performance. We find support for a fully mediated model, utilizing a sample of 163 Swiss family firms. Family ownership was shown to positively influence the development of a family firm image. High family expectations of the firm leader was shown to promote a family firm image and risk taking. In turn, risk taking and family firm image contributed to firm performance. Accordingly, our study identifies why family ownership and family expectations can benefit family firm performance-through their influence on family firm image and entrepreneurial risk taking.
\end{abstract}

Published by Elsevier Ltd.

\section{Introduction}

An entrepreneurial orientation provides the entrepreneurial mindset and organizational impetus necessary for corporate entrepreneurship (Lumpkin \& Dess, 1996; Memili, Lumpkin, \& Dess, 2010). Entrepreneurial orientation is a multidimensional construct, which includes dimensions of risk taking, autonomy, innovativeness, proactiveness, and competitive aggressiveness (Lumpkin \& Dess, 1996). In family firms, an entrepreneurial orientation is critical because it can contribute to transgenerational succession when it endures across generations (Chrisman, Chua, \& Steier, 2003, p. 443). The underlying emphasis on the future and sustainability of the business makes the risk-taking

\footnotetext{
An earlier version of this paper has been published as book chapter in the Advances in Entrepreneurship, Firm Emergence and Growth, v. 12.

* Corresponding author.

E-mail addresses: esramemili@gmail.com (E. Memili),

k.eddleston@Neu.edu (K.A. Eddleston), kellermanns@utk.edu (F.W. Kellermanns), thomas.zellweger@unisg.ch (T.M. Zellweger), tbarnett@cobilan.msstate.edu (T. Barnett).

${ }^{1}$ Tel.: +1 6626171459 .

2 Tel.: +1 617373 4014; fax: +1 6173738628 .

3 Tel.: +1 8649730835 .

4 Tel.: +41712247100.

5 Tel.: +1 662325 2419; fax: +1 6623258651 .
}

dimension of entrepreneurial orientation particularly important to family firms as they pass on from one generation to the next (Zahra, 2005). Specifically, research suggests that reciprocal altruism, concern for future generations, job creation for family members, and social capital can facilitate entrepreneurial-risk taking in family firms (Arregle, Hitt, Sirmon, \& Very, 2007; Corbetta \& Salvato, 2004; Eddleston \& Kellermanns, 2007; Habbershon, Williams, \& MacMillan, 2003; Le Breton-Miller \& Miller, 2006; Miller \& Le Breton-Miller, 2005). Conversely, higher levels of ownership concentration and intentions to maintain family control of the business have been associated with risk aversion (GómezMejía, Haynes, Núñez-Nickel, Jacobson, \& Moyano-Fuentes, 2007; Schulze, Lubatkin, \& Dino, 2003). Several studies have demonstrated the risk aversion tendencies of family business owners (Gómez-Mejía, Núñez-Nickel, \& Gutierrez, 2001; Romano, A.Tanewski, \& Smyrnios, 2001; Schulze, Lubatkin, Dino, \& Buchholtz, 2001). Yet, the interplay between economic and noneconomic goals also makes the risk-taking tendencies of family firm leaders difficult to predict (Gómez-Mejía et al., 2007).

While there has been a call for research aiming to better understand family firms' risk taking propensity (Uhlaner, Kellermanns, Eddleston, \& Hoy, in press), family firm-specific advantages also need to be explored, focusing on how firms capitalize on stakeholders' impression of family firms (Habbershon \& Williams, 1999; Habbershon et al., 2003). Specifically, do firms that build a 
family firm image experience a competitive advantage? A family firm image is created when firm leaders choose to present the business as a "family firm" to stakeholders. These family owners see the firm as an extension of the family (Dyer, 1992; Dyer \& Whetten, 2006) and through branding and communication activities work to project a family firm image to stakeholders. Indeed, family firms tend to be regarded as particularly trustworthy entities (Tagiuri \& Davis, 1996; Ward \& Aronoff, 1995) and as strong contributors to their community (Steier, 2001). According to Dyer and Whetten (2006), a family firm image may be a central factor that contributes to family firm success. Therefore, while risk taking behavior may foster performance through bold initiatives, a family firm image may contribute to performance by parlaying a firm's family heritage and established reputation in the community.

However, to date, little research has empirically investigated entrepreneurial risk taking or image in family firms. Although family firms are often criticized for being risk-averse (GómezMejía et al., 2001; Schulze et al., 2001), we do not know if entrepreneurial risk taking is actually beneficial to family firm performance. Further, while family firms are seen as trustworthy and customer-oriented (Craig, Dibrell, \& Davis, 2008), we do not know if family firms should invest in building a family firm image. Accordingly, we aim to answer the following research questions: Why are some family firms more likely than others to take entrepreneurial risk and to build an image as a family business? Do entrepreneurial risk taking and family firm image contribute to family firm performance?

In this paper, we draw from organizational identity theory to fill this gap in the literature and to explain how entrepreneurial risk taking and family firm image might benefit family firm performance. Organizational identity theory is concerned with explaining "what we do as an organization" as well as "who we are as an organization" (Nag, Corley, \& Gioia, 2007). Indeed, previous research has tied organizational identity to strategic change (Nag et al., 2007) and firm image (Dyer \& Whetten, 2006; Whetten \& Mackey, 2005). Given our focus on family firms, we consider the family's influence on entrepreneurial risk taking and family firm image, by examining how the degree of family ownership in the firm and the family's expectations for the firm leader relate to its attempt to project a family firm image and engage in risk taking behavior.

Thus, this study contributes to the family firm literature in several ways. Our focus on organizational identity theory helps to demonstrate how the family has an enduring influence on the family firm-affecting investments in the firm's future through risk taking as well as exploiting the achievements of its past by building a strong family firm image. This study also contributes to the family business literature by demonstrating the effects of entrepreneurial risk taking and family firm image on family firm performance. Entrepreneurial risk taking may be an important way for family firms to remain competitive; however, this phenomenon needs to be better understood in family firms (Uhlaner et al., in press). Furthermore, a family firm image may be a way for family firms to differentiate themselves from non-family firms in the marketplace, particularly since they have control over the degree to which they communicate the strength and depth of their family ties to stakeholders.

In the remainder of this paper, we develop our model and hypotheses, describe the methodology, present our results, and suggest future research directions. In the section that follows, we begin with a discussion of organizational identity theory and family firm image, before we discuss risk taking in family firms. We then discuss family influences on risk taking and family firm image. Fig. 1 provides a visual representation of the hypothesized relationships.

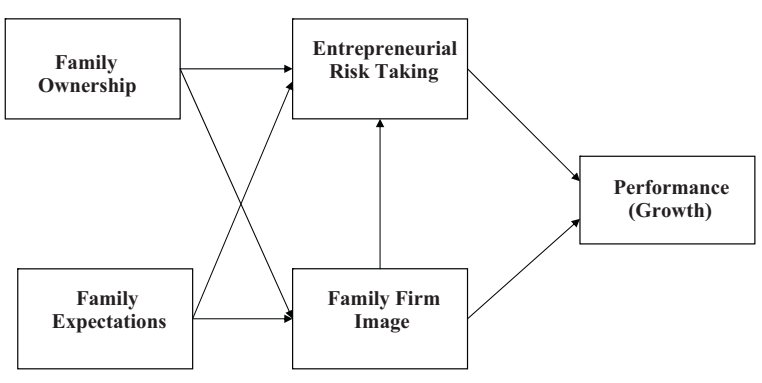

Fig. 1. Conceptual model.

\section{Theoretical overview}

\subsection{Family firm image}

Organizational identity answers the question, "Who are we as an organization?" (Albert \& Whetten, 1985), providing guidance to organizational members as they conduct their daily work (Nag et al., 2007). Organizational identity embodies organizational members' cognitive views of their organizations as well as their collective behaviors (Nag et al., 2007). In line with this perspective, we see organizational identity as a framework which guides a family firm's strategic behaviors and affects how managers attempt to portray their organization to the public (Scott \& Lane, 2000) in order to shape its external image and develop its reputation among stakeholder groups. For family firms, organizational identity is unique in that the family is a distinct, central, and enduring component of the firm.

Organizational identity approaches to the study of family firms might be particularly fruitful because organizational salience, attraction, and identification are enhanced by the demographic similarity of family members, which is a key characteristic of family firms (Hogg \& Terry, 2000). Seeing the family as one with the firm-sharing values, goals, and membership-can have a profound impact on organizational behavior. Family business members exhibit longer tenure than business members in nonfamily firms since family business membership often starts from childhood, continues through summer jobs, and extends into the life-long career of family business members, which can enhance salience of family business membership (Dutton, Dukerich, \& Harquail, 1994; Le Breton-Miller, Miller, \& Steier, 2004). Similarly, organizational identity studies suggest that identification is related to internalization of or adherence to organizational expectations, desire for group attachments, and ambitious and achievement-oriented pursuits (Mael \& Ashforth, 1995). These elements of organizational identity are relevant to family firms exhibiting an "enduring nature" based on image, trustworthy reputation, unified ownership and management by family members, creativity, attention to research and development, long-run orientation and expectations, and emphasis on company sustained performance (Habbershon \& Williams, 1999, p. 5). A strong organizational identity may therefore provide a beacon for family members, helping them to align their values with those of the organization and guide their decision-making.

Organizational identity helps individuals preserve their continuity of self-concept and provides distinctiveness and selfenhancement (Dutton et al., 1994). High levels of organizational identification with a family firm may elevate a family member's cooperation with organizational members and sense of competition with other organizations. Indeed, Dutton and colleagues (1994) argue that members with strong organizational identification tend to work on long-term projects and push superiors to raise standards and provide ideas for developing their organizations. Individuals identify with their organizations to the extent 
that they perceive an overlap between their individual identity and the identity of their organization (Foreman \& Whetten, 2002). Thus, in line with organizational identity theory, family members may see themselves as extensions of their firm, causing them to want to portray the family firm in a positive light (Dyer \& Whetten, 2006) and behave in ways that support family firm principles and goals.

Organizational image is related to organizational identity, but conceptually distinct. Organizational image relates to the way organizational members believe others see their organization (i.e., construed external image) and the way organizational leaders would like outsiders to see the organization (i.e., desired or communicated image) (Gioia \& Thomas, 1996; Ravasi \& Schultz, 2006; Scott \& Lane, 2000). Hence, image encompasses the internal conception of the organization and the intentional projection of it to outsiders (Dyer \& Whetten, 2006). Organizational identity theory suggests that firms work to project their organizational image and build a positive reputation among stakeholders by promoting attractive branding (Einwiller \& Will, 2002). A firm's brand represents a set of promises implying trust and consistency for customers (Craig, Dibbrell, \& Davis, 2008). Accordingly, the branding process involves a firm differentiating itself from competitors through advertising and promotion aimed to appeal to the market and highlight the integrity of the brand (Karreman \& Rylander, 2008; Miller \& Le Breton-Miller, 2006). Consequently, the successful creation and maintenance of a coherent brand can lead to a positive image, forming the basis for a favorable organizational reputation (Craig et al., 2008; Einwiller \& Will, 2002). Since "a positive reputation in the minds of key stakeholders may serve as a form of social insurance, protecting the firm's (and family's) assets in times of crisis" (Dyer \& Whetten, 2006, p. 785), firms have an incentive to create and maintain a positive image that can thereby lead to a positive reputation in the marketplace. Furthermore, a favorable reputation, derived from a positive image, allows organizations to charge a premium price, attract better job applicants, and provide better access to capital markets (Fombrun, 1998; e.g., Fombrun \& Shanley, 1990; Rindova, Williamson, Petkova, \& Sever, 2005), thus fostering firm success.

Organizational image may be an important concern particularly for family firm members since family businesses are often associated with the family name and a poor image "would soil the 'good name' of their family and, in turn, reflect poorly on them individually”(Dyer \& Whetten, 2006, p. 791). Unlike an employee in a non-family firm, a family member cannot switch families and therefore family members may be more likely to work together to preserve the family firm's good name (Dyer \& Whetten, 2006). Furthermore, family firms are often regarded as trustworthy (Tagiuri \& Davis, 1996; Ward \& Aronoff, 1995) and as placing great emphasis on maintaining long-term relationships (Sirmon \& Hitt, 2003). Indeed, Dyer and Whetten (2006) showed that family firms are more adept at avoiding socially irresponsible acts. Consistent with studies on organizational image and family firms' apparent need to sustain and project a favorable image, Craig et al. (2008) suggest that family firms with a positive image can subsequently build a reputation, capitalizing on customers' positive perception of family firms. Indeed, family firms are often perceived as customer-oriented and quality-focused (Cooper, Upton, \& Seaman, 2005; Sundaramurthy \& Kreiner, 2008). In turn, a strong family firm image, which can be a nonimitable resource, may generate a competitive advantage for family firms (Sundaramurthy \& Kreiner, 2008). Hence, we expect that a family firm image will be positively related to family firm performance.

Hypothesis 1. Family firm image is positively related to family firm performance.

\subsection{Entrepreneurial risk taking}

Risk relates to the "variation in the distribution of outcomes, their likelihoods, and their subjective values" and is "measured either by nonlinearities in the revealed utility for money or by the variance of the probability distribution of possible gains and losses associated with a particular alternative" (March \& Shapira, 1987, p. 1404). According to Shapira (1995, p. 126), risk taking differs from "playing the odds" or "gambling". Organizational studies draw attention to risk taking as an integral entrepreneurial function that can lead to success (Brockhaus, 1980; Shapira, 1995). This risk derives from both financial risk, involving the commitment of a large amount of assets and/or heavy borrowing, and the personal risk that executives take in making such decisions (Brockhaus, 1980; Lumpkin \& Dess, 1996; Lumpkin \& Lichtenstein, 2005). As a central dimension of entrepreneurial orientation, entrepreneurial risk taking is defined as "the degree to which managers are willing to make large and risky resource commitments, i.e., those which have a reasonable chance of costly failures" (Miller \& Friesen, 1978, p. 923). The notions of heavy borrowing, leveraging of assets, and heavy commitment of resources are consonant with this definition of risk taking (Lumpkin \& Dess, 2006). Such risks are often taken in the interest of obtaining high returns by seizing opportunities in the marketplace.

Economic theory assumes that many organizations tend to be risk-averse and will not be willing to undertake high risk unless a hefty return is expected (Singh, 1986). However, March and Shapira (1987, p. 1415) argue that risk is manageable and controllable through the "engineering of risk taking" and "risk management." Consistent with March and Shapira's argument, Dess and Lumpkin (2005) suggest that managers can research and evaluate risk factors in order to reduce uncertainty and apply useful techniques to manage risk. Hence, managers can modify risk rather than simply accept a particular level of risk. Managerial behavior tends to be shaped by reward systems, perceptions, cognitive biases, and shared understandings in a firm. Consequently, successful risk taking behavior can help a firm to outperform its competitors (Dess \& Lumpkin, 2005).

However, family firms are often seen as unwilling to take risks, take advantage of opportunities, grow, and develop (Habbershon \& Pistrui, 2002; Hall, Melin, \& Nordqvist, 2001; Ward, 1997; Wilken, 1979). They are portrayed as being reluctant to invest in new ventures (Cabrera-Suárez, Saá-Pérez, \& García-Almeida, 2001), assume risk (Morris, 1998), or induce change (Levinson, 1987). Some have also argued that family firms' entrepreneurial orientation diminishes at later stages of the business lifecycles due to established traditions and resistance to change (Hall et al., 2001; Ward, 1997). Over time, family firms become more focused on preserving wealth as opposed to creating wealth. Yet in order to provide for future generations and to remain competitive, entrepreneurial risk taking is necessary. Studies on family firms seem to suggest that entrepreneurial risk taking is pursued to ensure transgenerational sustainability and firm performance (Corbetta \& Salvato, 2004; Zahra, 2005). Accordingly, we predict that entrepreneurial risk taking will be positively related to family firm performance.

Hypothesis 2. Entrepreneurial risk taking is positively related to family firm performance.

\section{The family influence}

Given our inherent focus on family firms, we now consider how particular characteristics of the family may affect firm performance through their influence on entrepreneurial risk taking and 
family firm image. First, in order to consider the degree of family control and potential influence in the firm, we look at how family ownership affects risk taking and family firm image. Second, to assess the family's level of identification and concern for the firm, we consider how family expectations influence risk taking and family firm image. As such, we see risk taking and family firm image as mediators in our model that help to explain how the family can have a positive effect on family firm performance.

\subsection{Family ownership}

Organizational identification reflects the cognitive and emotional attachment that an individual has with his or her firm based on shared attributes (Nahapiet \& Ghoshal, 1998). Employees identify with their firms to the extent that they perceive an overlap between the identity of their organization and their individual identity (Dyer \& Whetten, 2006; Foreman \& Whetten, 2002). People are particularly likely to identify with their organizations when the organization contributes to their self-esteem, selfconsistency, and self-distinctiveness (Ashforth \& Mael, 1989; Scott \& Lane, 2000). In the context of family firms, a family member may identify with the family, the firm, or both. Just as family firm founders tend to view their businesses as extensions of themselves (Dyer, 1992; Dyer \& Whetten, 2006), the greater the degree of ownership family members have in the firm, the more likely their identity may be tied to the family firm.

Family ownership is significant "when a family owns all or a controlling portion of the business and plays an active role in setting strategy and in operating the business on a day-to-day basis" (Kelly, Athanassiou, \& Crittenden, 2000, p. 27). In most family firms, ownership and management are unified (Carney, 2005; Gersick, Davis, Hampton, \& Lansberg, 1997; Lubatkin, Schulze, Ling, \& Dino, 2005). Other family governance types are sibling partnerships where ownership is spread around members of one generation and cousin consortiums where ownership is transferred to third and later generations.

Because family control encourages families to protect their 'good name' (Dyer \& Whetten, 2006), family ownership may be positively related to family firm image. Due to their individual identity being entangled in the organization's identity, family members are likely to see customer complaints and firm mishaps as reflections of themselves and the family (Dyer \& Whetten, 2006; Post, 1993). Drawing from organizational identity theory, Dyer and Whetten explain that families work to maintain a positive image in their communities because "( 1 ) family members share a common need to view themselves positively (I am a good person); (2) they know they cannot switch families, if word of a shameful family activity "gets out," (3) so they band together to preserve the family reputation" (2006: 790). Furthermore, close monitoring and control by family owner/managers can elevate the quality of products or services and help build trust and goodwill with customers (Poppo \& Zenger, 2002; Sako, 1991; Tagiuri \& Davis, 1996; Ward \& Aronoff, 1991; Weigelt \& Camerer, 1988). Indeed, higher levels of family ownership may help family businesses to develop and sustain strong relationships with customers and other external stakeholders (Aronoff \& Ward, 1995; Dick \& Basu, 1994; Habbershon \& Williams, 1999; Lyman, 1991) that help to establish a strong image. As such, higher levels of family ownership may increase a family firm's tendency to project a family firm image in the marketplace. Therefore:

Hypothesis 3. Family ownership is positively related to family firm image.

Family firm studies suggest that family ownership can increase the possibility of growth (Habbershon \& Williams, 1999; Ward, 1997). Family ownership pushes firm leaders to grow their business so as to be worthy of succession. Furthermore, when decision-making is centralized among family members, flexibility increases, while costs decrease (Habbershon \& Williams, 1999). Carney (2005) explains how ownership provides family members with control rights and discretionary power over the firm's assets that allows them to influence and dominate decision-making processes in their firms. As a result, family firms can be more responsive to changes in the business environment through rapid decision-making facilitated by heuristics and intuition that can facilitate growth (Carney, 2005).

Additionally, family ownership significantly affects the strategic choices (e.g. risk taking) of the family firm (Zahra, 2003, 2005). Naldi, Nordqvist, Sjoberg, and Wiklund (2007) suggest that risk taking, a distinct dimension of entrepreneurial orientation, may be positively associated with proactiveness and innovativeness in family firms, thereby fostering success. Indeed, through identification with the organization, higher levels of family ownership may ensure that necessary risk taking activities will be pursued. Therefore, we expect family ownership to positively influence entrepreneurial risk taking.

Hypothesis 4. Family ownership is positively related to entrepreneurial risk taking.

\subsection{Family expectation}

Organizational identity research often focuses on how organizations create meaning for their employees, providing a cognitive frame in which to interpret their work practices and surroundings (Nag et al., 2007). Organizational members aim to align who they think they are as an organization with how they would like to be perceived by outsiders (Ravasi \& Schultz, 2006). They work to reaffirm positive aspects of their organizations in the interest of their own needs for self-esteem and self-consistency (Brown, 1997; Scott \& Lane, 2000). As organizational members' identification with their firm increases, so does their motivation to reach firm goals (Ashforth \& Mael, 1989). According to organizational identity theory, the most effective managers are "those whose self-concepts overlap so extensively with their organizations that organizational effectiveness is a prerequisite for their self-esteem" (Scott \& Lane, 2000: 56-57). As such, a strong organizational identity may help family firms to succeed by persuading family leaders to show concern for the firm's wellbeing and to work toward accomplishing firm goals. When firm leaders strongly identify with their organizations, they are motivated to cooperate with firm members and to pursue the firm's interests (Ashforth \& Mael, 1989). Therefore, we suggest that high family expectations, characterized as family leaders (CEOs) that share values with their firm and perceive their family posseses high standards regarding their work performance-affect entrepreneurial risk taking and family firm image concerns.

Specifically, in line with organizational identity theory, we argue that family expectations may contribute to family firm image. Since family leaders are likely to see the family as a key aspect that distinguishes the family firm, they may work hard to preserve the firm's image in the community (Dyer \& Whetten, 2006). Individuals have an innate need for positive self-image which causes individuals to prefer to belong to groups that are viewed positively by outsiders (Baumeister, 1998). Because family firm leaders, especially the CEO, may see their business as extensions of themselves as well as their family, strong family expectations may increase their concern for their family firm image. Indeed, Dyer and Whetten's (2006) study on organizational identity and image suggests that family firms work harder than their non-family firm counterparts to avoid social problems and firm mishaps. They later explained that "a family that owns an 
enterprise with its 'name on the building' may... feel a greater responsibility" to protect the family image (Dyer \& Whetten, 2006: 797). Accordingly, we hypothesize:

Hypothesis 5. Family expectations are positively related to family firm image.

Similarly, when family expectations are high, family leaders should strive to sustain the family business, creating wealth and jobs for future generations by engaging in risk taking activities. Continuously focusing family leaders' efforts on achievement and superior work performance may keep family firms from becoming stagnant or outdated. The expectation for family leaders to contribute to the firm may also encourage these leaders to invest in the firm's future by pursuing entrepreneurial initiatives. Indeed, organizational identity theory suggests that positive reinforcement from peers regarding one's identity motivates individuals to pursue firm goals and success (i.e. Scott \& Lane, 2000).

Hypothesis 6. Family expectations are positively related to entrepreneurial risk taking.

Lastly, we argue that family firm image is related to entrepreneurial risk taking. A family that actively works to create a family firm image may also be more aggressive and active regarding entrepreneurial risk taking. Family business members, whose selfesteem, self-integrity, and self-worth are tied to the family firm's image (Dutton et al., 1994; Smidts, Pruyn, \& Van Riel, 2001), may be especially motivated to take entrepreneurial risk since organizational growth would reflect positively upon them. Indeed, studies suggest that a strong organizational identity can promote change and growth in organizations (e.g., Davide \& Van Rekom, 2003). Accordingly, Fillis (2003) points out that firm image, derived from organizational identity, lies at the heart of entrepreneurial endeavors. Hence, a strong family firm image may encourage family members to pursue entrepreneurial risk. Formally stated:

Hypothesis 7. Family firm image is positively associated with entrepreneurial risk taking.

\section{Method}

\subsection{Sample}

A mailing list of 1250 privately held Swiss family firms was obtained by a family firm center associated with a major Swiss university. As is common in family firm research, we collected the data via a mail survey approach (e.g., Eddleston \& Kellermanns, 2007). In order to verify that the firms in our sample were family firms, we first ensured that the firm had identified itself as a family business to the university center. Second, we only considered those firms that reported having at least two family employees (e.g., Eddleston \& Kellermanns, 2007; Eddleston, Kellermanns, \& Sarathy, 2008).

For the purpose of this study, we relied on the CEO as a knowledgeable respondent (Kumar, Stern, \& Anderson, 1993; Seidler, 1974). This focus is particularly appropriate since CEOs in family firms tend to be responsible for entrepreneurial behavior. Indeed, family firm research focusing on entrepreneurial behavior has previously utilized this approach (e.g., Kellermanns, Eddleston, Barnett, \& Pearson, 2008; Zahra, 2005). Overall, 163 usable responses from family firm CEOs were obtained, representing a $13 \%$ response rate. This response rate compares to similar survey based studies (e.g., Chrisman, Chua, Chang, \& Kellermanns, 2007; Cycyota \& Harrison, 2002; Simonin, 1997).

To address non-response bias concerns, we first compared early and late respondents utilizing an analysis of variance. We did not discover any significant differences between the two groups. Since no differences were observed, concerns about non-response bias were diminished to some extent (for a recent example see Chrisman, McMullan, \& Hall, 2005). We further assessed concerns for common method bias by performing an exploratory factor analysis where all items utilized in our study were entered (Podsakoff \& Organ, 1986). This revealed 5 factors with Eigenvalues $>1.0$, which accounted for $67.32 \%$ of the variance. The first factor in the analysis accounted for $25.69 \%$ of the variance and no common method factor emerged, which reduced our concerns related to common method variance.

\subsection{Measures}

All items used to assess the dependent, independent and mediating variables are listed in the appendix. Below, we discuss each measure in turn.

\subsubsection{Dependent variable-family firm performance (growth)}

Prior research on entrepreneurial behavior has focused on

growth related performance outcomes (Kellermanns et al., 2008) and scholars suggest that the firm's growth rate is a reliable, if not a superior performance measure in family firms (e.g., Kellermanns et al., 2008; Schulze et al., 2001). Indeed, compared to other performance measures, growth measures are less likely to be underreported (Daily \& Dollinger, 1992; Dess \& Robinson, 1984; Schulze et al., 2001). Accordingly, we assessed performance via sales growth and market share growth. Both were measured on a 7-point Likert-type scale by asking CEOs if their growth in sales and market share was currently, and in the last three years, much worse to much better than that of their competitors.

\subsubsection{Independent variables and mediators}

We assessed total family ownership by asking a single question: "What percentage of equity is owned by the family?" We expanded the two item scale of family expectations from Beehr, Drexler, and Faulkner (1997) by adding a third item to better reflect the family firm context. The items were measured on a 7-point Likert-type scale. Coefficient alpha for this measure was .69.

We assessed entrepreneurial risk taking based on the entrepreneurial behavior dimension of risk-taking. As can be seen in the Appendix, the 7-point scale was anchored by two items at opposite ends of a continuum. We used three items presented in (Barringer \& Bluedorn, 1999), which were earlier developed by Miller and Friesen (1982) and Covin and Slevin (1988). The alpha for this measure was .83. Our family firm image measure was inspired by Dyer and Whetten's article (2006) and was created to assess the degree to which the organization attempts to create a family firm's image. Some of the items in our 6-item scale are: "The family firm name is recognized in the community"; "The family name is used as brand"; and "The fact that we are a family business is a great marketing tool." The items were measured on a 7-point Likert-type scale. Alpha for this measure was .75 .

\subsubsection{Control variables}

Lastly, we utilized several relevant control variables. We included industry controls (construction, wood processing, engineering, business services, manufacturing), to capture the varying levels of entrepreneurial activities by industry (Capon, Farley, \& Hoenig, 1990). We also included firm age, since younger firms could have higher growth potential, as well as firm size (Kellermanns \& Eddleston, 2006). However, none of these controls had a significant impact and were thus omitted from the structural equation model for the sake of parsimony and to enhance interpretability of the model. 
Table 1

Descriptive statistics and correlations.

\begin{tabular}{lrrllll}
\hline Variables & Mean & \multicolumn{1}{l}{ SD } & 1. & \multicolumn{1}{l}{ 2. } & 3. & \multicolumn{1}{l}{4} \\
\hline 1. Family ownership & 87.20 & 26.36 & & & & \\
2. Family expectations & 6.08 & .73 & .10 & & & \\
3. Entrepreneurial risk taking & 4.05 & 1.16 & .06 & $.26^{* * *}$ & & \\
4. Family firm image & 4.95 & 1.21 & $.15^{\dagger}$ & $.34^{* * *}$ & $.26^{* * *}$ & \\
5. Performance (growth) & 4.63 & 1.14 & .09 & .05 & $.25^{* * *}$ & $.22^{* *}$ \\
\hline
\end{tabular}

$N=163$

$\dagger p<.10$.

${ }^{* *} p<.01$.

$p<.001$.

\section{Results}

We analyzed the data using AMOS $16^{\mathrm{TM}}$ and SPSS $15.0^{\mathrm{TM}}$, and used structural equation modeling with maximum likelihood estimation to test our hypotheses. The correlations, means and standard deviations are displayed in Table 1.

We took a multi-step approach in our study (e.g., Eddleston \& Kellermanns, 2007; Martins \& Kellermanns, 2004). First, we estimated a measurement model (CFA) in order to ensure a clean factor loading of our model. In a second step, we estimated our hypothesized full mediation model, where the effects of our independent variables are fully mediated by entrepreneurial risk taking and family firm image. In a last step, we tested for the possibility of partial mediation and conducted model comparisons. Each procedure is discussed in more detail below.

First, we estimated a measurement model (CFA) including all variables and all items. In order to assess the fit of our model, we used multiple fit indices. Specifically, we used the chi-square statistic $\left(\chi^{2}\right)$, comparative fit index (CFI), incremental index of fit (IFI), and Tucker-Lewis index (TLI). Larger values of CFI, IFI and TLI (.90 or above) denote a good fit of a model to the data. Additionally, the root mean square error of approximation (RMSEA) for the models was investigated. A RMSEA lower than .08 is suggested to indicate good fit (Hu \& Bentler, 1995; Kline, 1998; Mulaik, James, Alstine, Bennett, Ling, \& Stilwell, 1989). The measurement model showed acceptable fit, a clean factor structure, with CFI $=.845$, $\mathrm{IFI}=.848$, TLI $=.804$, RSMEA $=.106$ and $\chi^{2}(95)=268.202$, particularly considering our sample size in conjunction with the number of indicators utilized. We did not parcel the items in order to retain full information.

The convergent validity of our constructs was assessed in three ways. First, the factor loadings under each construct in Appendix A exceeded the threshold level of .5 (Hair, Black, Babin, Anderson, \& Tatham, 2006). Second, we calculated the average variance extracted (AVE) for our multi-item constructs: AVE family expectations $=45.37 \%$, AVE entrepreneurial risk-taking 63.75\%, AVE family firm image $=41.9 \%$, and AVE performance $=80.33 \%$. AVE scores of .5 or higher indicate adequate convergent validity (Hair et al., 2006). Two constructs, family expectations $($ AVE $=45.37 \%)$ and family firm image (AVE $=41.9 \%)$ fell below the minimum threshold of .5. However, given the exploratory nature of our study and the acceptable levels of the other indicators, we considered the convergent validity of our model's constructs to be sufficient (Hair et al., 2006). Third, we calculated the construct reliabilities $(\alpha)$ as reported in Appendix A. Values of .7 or higher suggest good reliability (Hair et al., 2006). Only one construct, family expectations ( $\alpha=.69$ ), was marginally below the .7 threshold. As stated earlier, given the exploratory nature of our study and the acceptable levels of the other indicators for construct validity, we considered the reliability of this construct to be adequate (Hair et al., 2006). Finally, to establish discriminant validity of our constructs, we compared the AVE scores to the squared inter-construct correlations. All AVE scores were substan-

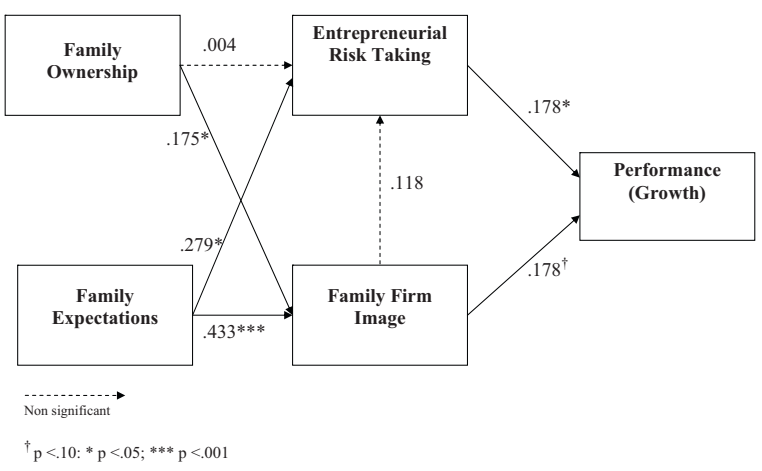

Fig. 2. Standardized path loadings for hypothesized model.

tially larger than the squared inter-construct correlations (Hair et al., 2006), showing discriminant validity.

In a second step, we estimated a two-nested model to establish full or partial mediation. In order to improve the fit, we allowed the sales growth and market share growth of the respective time period to covary. Our findings support the hypothesized model of full mediation with $\chi^{2}(96)=206.614, \quad$ CFI $=.901, \quad$ IFI $=.903$, $\mathrm{TLI}=.876$, and RMSEA $=.084$ (Hu \& Bentler, 1995; Kline, 1998; Mulaik et al., 1989). We then compared the fit of our hypothesized model with the partially mediated model, whereby we allowed the independent variables to directly load onto the dependent variable. None of these paths were significant, indicating full mediation. Indeed, the chi-square comparison test: $\chi^{2}$ difference $(96-94)=206.614-204.541=2.044$ n.s. indicates that the fully mediated model is superior. Accordingly, we report our findings pertaining to the fully mediated model in more detail below. The standardized path loadings, estimated via maximum likelihood estimation, are presented in Fig. 2.

Hypothesis 1 was marginally supported, since the relationship between family firm image and family firm performance $(\beta=.178$, $p<.10$ ) was only marginally significant. However, our second hypothesis, stating that entrepreneurial risk taking behavior would be positively related to growth received statistical support $(\beta=.178, p<.05)$.

Hypotheses 3 and 4 argued that higher levels of family ownership are positively related to family firm image and entrepreneurial risk taking, respectively. The relationship between family ownership and family firm image was significant $(\beta=.175, p<.05)$. However, no significant relationship was observed between family ownership and entrepreneurial risk taking. Hypotheses 5 and 6 received support. Family expectations were related to both family firm image $(\beta=.433, p<.001)$ and entrepreneurial risk-taking $(\beta=.279$, $p<.05)$.

Lastly, Hypothesis 7 was not supported. We argued that family firm image would enhance risk taking behavior. This relationship was not significant. However, we cannot fully exclude the possibility that due to our cross-sectional design, entrepreneurial risk taking could cause higher levels of family firm image. In an analysis not reported here, the reversed relationship was also found not significant.

Overall, the squared multiple correlation of family firm image, which equals $R^{2}$ in structural equation modeling (e.g., Straub, Limayem, \& Karahanna-Evaristo, 1995), was .218, suggesting that $21.8 \%$ of the variance of family firm image was explained in our model. The model furthermore explained $11.8 \%$ of the variation in entrepreneurial risk taking and $7.9 \%$ of family firm performance variance.

\section{Discussion}

Overall, our empirical results provided support, to varying degrees, for five of the seven hypothesized relationships. First of 
all, as expected, family firm image and entrepreneurial risk taking were linked with family firm performance in regards to relative growth in sales and market share, although the relationship between family firm image and performance was somewhat more modest $(p<.10)$ than that between risk taking and performance $(p<.05)$. Further, consistent with our predictions derived from organizational identity theory, family expectations were found to be associated with both entrepreneurial risk taking and family firm image, in our sample of family firms. Thus, our results suggest an indirect effect of family expectations on family firm performance. Contrary to our expectations, we did not find a link between family ownership and entrepreneurial risk taking. However, we did find a positive, albeit modest, relationship between family ownership and family firm image, which suggests that family ownership may also have indirect effects on family firm performance. Finally, the analysis did not support the hypothesized relationship between family firm image and risk taking.

Our finding that family firm image has a marginally statistically significant relationship with performance adds to previous discussions on the importance of image to family firms (Berrone, Cruz, Gómez-Mejía, \& Larraza Kintana, 2010; Craig et al., 2008; Dyer \& Whetten, 2006; Tagiuri \& Davis, 1996; Ward \& Aronoff, 1995). Previous research suggests that the projection of a family firm image in the marketplace can lead to improved performance in achieving both non-economic and economic goals. Our study provides preliminary evidence that family firm image may benefit performance, at least in terms of relative growth in sales and market share compared to competitors.

The finding that entrepreneurial risk taking was associated with family firm performance supports the notion that aspects of an entrepreneurial orientation may be crucial for family firms who wish to achieve transgenerational succession (Chrisman et al., 2003) and/or preserve the socio-emotional wealth of the firm (Gómez-Mejía et al., 2007). This finding is particularly interesting because previous research has suggested that family firms tend to be more risk averse than non-family firms (Gómez-Mejía et al., 2001; Schulze et al., 2001). Thus, entrepreneurial risk taking could be an important explanatory variable related to relative levels of performance between family and non-family firms.

Contrary to our prediction, we did not find a link between family ownership and entrepreneurial risk taking. However, there was a statistically significant relationship between family ownership and family firm image. Organization identity theory suggests that an organization contributes to one's self-concept (Ashforth \& Mael, 1989) and that individuals will identify with an organization to the extent that they perceive an overlap between the identity of their organization and their individual identity (Dyer \& Whetten, 2006). Our finding that the degree of family ownership relates to the projection of a family firm image is consistent with organization identity theory. However, the lack of a significant relationship between family ownership and risk taking, coupled with the relatively weak association between family ownership and family firm image, suggests that further research is needed to clarify the precise role of family ownership as an influence on these variables (e.g., Steier, 2001; Ward \& Aronoff, 1995).

Our results related to family expectations, risk taking, and family firm image were somewhat stronger. We found that family expectations were associated with both risk taking and family firm image. It appears that stronger family expectations will lead a family firm CEO to engage in higher levels of risk taking. In turn, these entrepreneurial risk taking activities are positively related to family firm performance. Similarly, we also found a link between family expectations, family firm image and family firm performance. Hence, in line with organizational identity theory (Dyer \& Whetten, 2006; Foreman \& Whetten, 2002), we found that high family expectations strengthened the family image of the firm. In turn, family firm image contributed to performance, perhaps due to greater recognition in the marketplace and the public's positive perception of family firms.

Although not explicitly hypothesized, we need to briefly comment on the overall nature of the model. With the help of structural equation modeling, we were able to show that a fully mediated model fit our data best, showing, for example, that the possible relationship between family expectations and family firm performance was fully mediated by family firm image and risk taking. This finding demonstrates the importance of imagecreating activities and corporate entrepreneurship to family firm growth, and supports the conceptual suppositions of organizational identity theory.

Further, our findings contribute to our understanding of entrepreneurial risk taking in the family firm context. In particular, our results suggest that family expectations have a positive impact on entrepreneurial risk taking. While a family-related business culture may foster an entrepreneurial orientation (Nordqvist, in press), our results demonstrate that family expectations of the CEO encourages entrepreneurial risk taking in family firms, which ultimately enhances firm growth. As such, we see that CEOs' who believe their family has high expectations regarding their performance are motivated to pursue more risky endeavors.

Also, we add to the organizational identity perspective of family firms. Reaching beyond conceptual and preliminary empirical research applying organizational identity theory to the case of family firms (Anderson \& Reeb, 2003; Dyer \& Whetten, 2006; Sirmon \& Hitt, 2003; Steier, 2001), we provide empirical evidence that family firm image indeed has a positive impact on the reported performance of this type of organization. More importantly, we add to organizational identity theory in the context of family firms by considering family expectations as an indirect effect on growth in this type of organization, through two effects. That is, we demonstrated that family expectations encourage family firm leaders to build a family firm image and to take more risks, which ultimately benefit firm growth. Further, these findings suggest that the perceived assessment and opinions of peers, particularly fellow family members, can have a profound impact on a family firm's leader. Accordingly, future research should consider the role of the family in influencing family firm leaders' identification with the firm and the associated effects.

\subsection{Limitations, implications and future research}

First, we need to mention the organizational context of our study, which was set in Switzerland. Recent research has highlighted the importance of context in studies (Johns, 2006) and it is possible that this cultural setting influenced the strength of the observed relationships and thus the generalizability of our results to the US and other regions. However, while cultural differences exist (Hofstede, 2001), it has been argued that due to increased globalization European and US business practices are becoming more and more similar (Carr, 2005). Thus, we do not believe that the context significantly affected our findings; although we encourage future studies to replicate and extend our model in the US, and to utilize a multi-country design.

Second, we need to mention that the mailing list was obtained from a major international accounting firm and was not a random sample. However, less than $3 \%$ of the sample were customers of the accounting firm, and thus we do not believe that this biased the observed relationships. When compared with a national Swiss samples (Volery, Bergmann, Gruber, Haour, \& Leleux, 2007), the 2005 Swiss National Business Finance (SNFB) Survey (Daeppen \& Roth, 2005), our sample was comprised of slightly larger firms, but the age of the respondents was similar. However, here again, we do not expect this to have influenced our results. 
Third, our study was cross-sectional in nature and common method bias could be a concern (Podsakoff \& Organ, 1986). However our Harman's single factor test should alleviate concerns. While research suggests that common method problems are not likely to affect observed relationships (Doty \& Glick, 1998; Spector, 2006), we cannot rule out that the observed relationships may have been affected. We further need to mention that the variance explained in terms of firm performance was not high (7.9\%). However, considering our parsimonious model and the statistical and practical convention that variance explaining $\geq 1 \%$ is considered the statistical and practical threshold (Aguinis, 2004; Chrisman, Chua, \& Kellermanns, 2009), we believe our findings are meaningful, while at the same time see the need for future research.

Fourth, while our alphas were satisfactory and our confirmatory factor analysis showed an acceptable fit, we have to acknowledge that the fit indices are at the lower boundary levels. Although the factors did not exhibit any cross-loadings, the lower fit indices may be the result of a combination of a small sample size for structural equation modeling, the inclusion of all items (we did not utilize parceling procedures) and the lower, but acceptable reliability of some of our constructs. Additionally, the AVE of some of our constructs was not as high as it would have been desirable. Accordingly, we hope that future research will improve on the convergent validity of our measures.

Lastly, our performance indicator was self-reported. While we encourage future research to utilize objective performance data, these objective measures are often not available for firms that are not publicly traded. Prior research has shown that self-reported and actual performance measures are highly correlated in family firms (Ling \& Kellermans, 2010). Furthermore, our performance measures compare the family firm's performance with their respective competitors' performance. Accordingly, our measure is likely to take industry and rent appropriation effects into account (c.f., Coff, 1999).

Our findings show the importance and potential growth impact that family expectations of the CEO can have for a family firm. Our findings therefore identify a specific family effect that can help family firms succeed. However, future research is encouraged to further investigate family expectations, and whether excessively high expectations can turn into detrimental pressures for both the family and the family CEO, which may ultimately hurt performance.
Investigating this question is not only relevant in the context of ongoing family leadership, but also in the context of succession, particularly family expectations for successors before and after the transfer of leadership, and how these expectations impact strategic decisions and performance.

Our paper focuses on entrepreneurial risk taking as an important dimension of entrepreneurial orientation (Lumpkin \& Dess, 1996; Memili et al., 2010). However, entrepreneurial orientation is a multidimensional phenomenon that includes autonomy, innovativeness, risk taking, proactiveness, and competitive aggressiveness (Lumpkin \& Dess, 1996). Family firm research has only begun to look at corporate entrepreneurship (e.g., Eddleston, Kellermanns, \& Zellweger, in press; Kellermanns \& Eddleston, 2006; Naldi et al., 2007) or specific dimensions of entrepreneurial behavior (e.g., Kellermanns, Eddleston, Sarathy, \& Murphy, in press; Zahra, 2005). Thus, future research is necessary to clarify how the family influences specific entrepreneurial processes in family firms.

Our paper also has implications for other lines of research, in particular the resource-based view of the firm and the dynamic capabilities approach, since image can be seen as a firm's capability. As Makadok (2001, p. 389) suggests, capability is "a special type of resource-specifically an organizationally embedded nontransferable firm-specific resource whose purpose is to improve the productivity of the other resources possessed by the firm". Accordingly, image, exhibiting characteristics of a capability, cannot be bought but must be built (Teece, Pisano, \& Shuen, 1997). Hence, studies that draw from the resource based view and dynamics capabilities approach can shed light on the relationships between family involvement, family firm image, and their consequences.

\section{Conclusion}

In conclusion, this study draws from organizational identity theory to explore family firm image and entrepreneurial risk taking in family firms. Our findings confirm that family expectations provide incentives to maintain high levels of family firm image and encourage entrepreneurial risk taking. Our study further highlights the positive growth effects that can be achieved through family firm image and entrepreneurial risk taking behavior in family firms. Overall, our study shows that the family can serve as a unique asset and strength for the firm.

\section{Appendix A}

Scale items and reliabilities.

\begin{tabular}{|c|c|c|c|}
\hline Construct & Items & Item loadings & $\alpha$ \\
\hline \multicolumn{4}{|l|}{ Independent variables } \\
\hline Family ownership & Percentage of ownership held by the family & & - \\
\hline \multirow[t]{3}{*}{ Family expectations } & The family has high expectations for me when I am doing my work & .79 & .69 \\
\hline & The family is especially concerned that I do a good job at work & .68 & \\
\hline & The values of the family firm are comparable with my values & .52 & \\
\hline \multicolumn{4}{|c|}{ 20 } \\
\hline \multirow[t]{6}{*}{ Entrepreneurial risk taking } & In general, the top managers of my firm favor... (anchored by) & & .83 \\
\hline & Low-risk projects with normal and certain rates of return & .66 & \\
\hline & High-risk projects with chances of very high returns & & \\
\hline & A cautious, "wait and see" posture in order to minimize the probability of costly errors & & \\
\hline & $\begin{array}{l}\text { A bold, aggressive posture in order to maximize the probability of exploiting potential } \\
\text { Gradually exploring via cautious behavior }\end{array}$ & .91 & \\
\hline & Bold, wide-ranging acts to achieve objectives & .80 & \\
\hline \multirow[t]{5}{*}{ Family firm image } & The family firm name is recognized in the community & .57 & .75 \\
\hline & The family name is used as brand & .53 & \\
\hline & In our advertisement, we mention that we are a family business & .61 & \\
\hline & Most of our customers know that we are a family business & .72 & \\
\hline & The fact that we are a family business is a great marketing tool & .78 & \\
\hline
\end{tabular}


Appendix A (Continued)

\begin{tabular}{lll}
\hline Construct & Items & \multicolumn{1}{c}{ Item loadings } \\
\hline $\begin{array}{l}\text { Dependent variable } \\
\text { Performance (growth) }\end{array}$ & How would you rate your firm's performance as compared to your competitors? \\
& (7 point scale: worse, the same, better) & Growth in sales (two questions: current and past three years) \\
& Growth in market share (two questions: current and past three years) \\
\hline
\end{tabular}

\section{References}

Aguinis, H. (2004). Regression analysis for categorical moderators. New York: The Guilford Press.

Albert, S., \& Whetten, D. A. (1985). Organizational identity. In Cummings, L. L., \& Staw, B. M. (Eds.), Research in organizational behavior (Vol. 7, pp. 263-295). Greenwich, CT: JAI Press.

Anderson, R., \& Reeb, D. (2003). Founding-family ownership and firm performance: Evidence from S\&P 500. Journal of Finance, 58(3), 1301-1327.

Aronoff, C. E., \& Ward, J. L. (1995). Family-owned businesses: A think of the past or model of the future? Family Business Review, 8(2), 121-130.

Arregle, J.-L., Hitt, M. A., Sirmon, D. G., \& Very, P. (2007). The development of organizational social capital: Attributes of family firms. Journal of Management Studies, 44, 72-95.

Ashforth, B. E., \& Mael, F. (1989). Social identity theory and the organization. Academy of Management Review, 14, 20-39.

Barringer, B. R., \& Bluedorn, A. C. (1999). The relationship between corporate entrepreneurship and strategic management. Strategic Management Journal, 20, 421444

Baumeister, R. F. (1998). The self. In D. T. Gilbert, S. T. Fiske, \& G. Lindzey (Eds.), The handbook of social psychology. Boston, MA: McGraw Hill.

Beehr, T. A., Drexler, J. A., Jr., \& Faulkner, S. (1997). Working in small family businesses: Empirical comparisons to non-family businesses. Journal of Organizational Behavior, 18, 297-312.

Berrone, P., Cruz, C. C., Gómez-Mejía, L. R., \& Larraza Kintana, M. (2010). Socioemotional wealth and corporate response to institutional pressures: Do family-controlled firms pollute less? Administrative Science Quarterly, 55(1), 82-113.

Brockhaus, R. H. (1980). Risk taking propensity of entrepreneurs. Academy of Management Journal, 23(3), 509-520.

Brown, A. D. (1997). Narcissism, identity, and legitimacy. Academy of Management Review, 22, 643-686.

Cabrera-Suárez, K., Saá-Pérez, P. D., \& García-Almeida, D. (2001). The succession process from a resource- and knowledge-based view of the family firm. Family Business Review, 14(1), 37-47.

Capon, N., Farley, J. U., \& Hoenig, S. (1990). Determinants of financial performance: A meta analysis. Management Science, 36(10), 1143-1159.

Carney, M. (2005). Corporate governance and competitive advantage in family-controlled firms. Entrepreneurship Theory and Practice, 29(3), 249-266.

Carr, C. (2005). Are German, Japanese and Anglo-Saxon strategic decision styles still different in the context of globalization? Journal of Management Studies, 42(6), $1155-1188$

Chrisman, J. J., Chua, J. H., Chang, E. P., \& Kellermanns, F. W. (2007). Are family managers agents or stewards? An exploratory study in privately held family firms. Journal of Business Research, 60, 1030-1038.

Chrisman, J. J., Chua, J. H., \& Kellermanns, F. W. (2009). Priorities, resource stocks, and performance in family and non-family firms. Entrepreneurship Theory and Practice, 33(3), 739-760.

Chrisman, J. J., Chua, J. H., \& Steier, L. P. (2003). An introduction to theories of family business. Journal of Business Venturing, 18, 441-448.

Chrisman, J. J., McMullan, E., \& Hall, J. (2005). The influence of guided preparation on the long-term performance of new ventures. Journal of Business Venturing, 20, 769 791.

Coff, R. W. (1999). When competitive advantage doesn't lead to performance: The resource based view and stakeholder bargaining power. Organization Science, $10(2), 119-133$

Cooper, M. J., Upton, N., \& Seaman, S. (2005). Customer relationship management: A comparative analysis of family and nonfamily business perspectives. Journal of Small Business Management, 43(3), 242-256.

Corbetta, G., \& Salvato, C. (2004). Self-serving or self-actualizing? Models of man and agency costs in different types of family firms: A commentary on comparing the agency costs of family and non-family firms: Conceptual issues and exploratory evidence. Entrepreneurship Theory and Practice, 28(4), 355-362.

Covin, J. G., \& Slevin, D. P. (1988). The influence of organizational structure on the utility of an entrepreneurial top managemnt style. Journal of Management Studies, 25 217-234.

Craig, J., Dibbrell, C., \& Davis, P. S. (2008). Leveraging family-based brand identity to enhance firm competitiveness and performance in family businesses. Journal of Small Business Management, 46(3), 351-371.

Cycyota, C. S., \& Harrison, D. A. (2002). Enhancing survey response rates at the executive level: Are employee- or consumer-level techniques effective? Journal of Management, 28(2), 151-176.

Daeppen, M., \& Roth, V. (2005). Swiss national business finance survey. Bern: Swiss National Institute of Statistics.
Daily, C. M., \& Dollinger, M. J. (1992). An empirical examination of ownership structure in family and professionally managed firms. Family Business Review, 5(2), 117-136.

Davide, R., \& Van Rekom, J. (2003). Key issues in organizational identity and identification theory. Organizational Reputation Review, 6(2), 118-132.

Dess, G., \& Lumpkin, G. T. (2005). Entrepreneurial orientation as a source of innovative strategy. In S. S. Floyd, J. Roos, C. D. Jacobs, \& F. W. Kellermanns (Eds.), Innovating strategy process. Oxford: Blackwell Publishing.

Dess, G. G., \& Robinson, R. B. (1984). Industry effects and strategic management research. Journal of Management, 16(7), 7-27.

Dick, A. S., \& Basu, K. (1994). Customer loyalty: Toward an integrated conceptual framework. Journal of the Academy of Marketing Science, 22(2), 99-113.

Doty, D. H., \& Glick, W. H. (1998). Common methods bias: Does common methods variance really bias results? Organizational Research Methods, 1, 374-406.

Dutton, J. E., Dukerich, J. M., \& Harquail, C. V. (1994). Organizational images and member identification. Administrative Science Quarterly, 39, 239-263.

Dyer, G., \& Whetten, D. A. (2006). Family firms and social responsibility: Preliminary evidence from the S\&P 500. Entrepreneurship Theory and Practice, 30(6), 785-802.

Dyer, W. G. (1992). The entrepreneurial experience. San Francisco: Jossey-Bass.

Eddleston, K., \& Kellermanns, F. W. (2007). Destructive and productive family relationships: A stewardship theory perspective. Journal of Business Venturing, 22(4), 545 565.

Eddleston, K., Kellermanns, F. W., \& Sarathy, R. (2008). Resource configuration in family firms: Linking resources, strategic planning and environmental dynamism to performance. Journal of Management Studies, 45(1), 26-50.

Eddleston, K., Kellermanns, F. W., \& Zellweger, T. (in press). Corporate entrepreneurship in family firms: A stewardship perspective. Entrepreneurship Theory and Practice.

Einwiller, S., \& Will, M. (2002). Towards an integrated approach to corporate branding An empirical study. Corporate Communications: An International Journal, 7(2), 100109

Fillis, I. (2003). Image, reputation, and identity issues in the arts and crafts organization. Corporate Reputation Review, 6(3), 239-251.

Fombrun, C. J. (1998). Indices of corporate reputation: An analysis of media rankings and social monitors' ratings. Corporate Reputation Review, 1(4), 327-340.

Fombrun, C. J., \& Shanley, M. (1990). What's in a name? Reputation building and corporate strategy. Academy of Management Journal, 33(1), 233-258.

Foreman, P., \& Whetten, D. A. (2002). Members' identification with multiple-identity organizations. Organization Science, 13(6), 618-635.

Gersick, K. E., Davis, J. A., Hampton, M. M., \& Lansberg, I. (1997). Generation to generation: Life cycles of the family business. Boston, MA: Harvard Business School Press.

Gioia, D. A., \& Thomas, J. B. (1996). Identity, image, and issue interpretation: Sensemaking during strategic change in academia. Administrative Science Quarterly, 41 370-403.

Gómez-Mejía, L. R., Haynes, K. T., Núñez-Nickel, M., Jacobson, K. J. L, \& MoyanoFuentes, H. (2007). Socioemotional wealth and business risk in family controlled firms: Evidence from Spanish olive oil mills. Administrative Science Quarterly, 52(1), 106-137.

Gómez-Mejía, L. R., Núñez-Nickel, M., \& Gutierrez, I. (2001). The role of family ties in agency contracts. Academy of Management Journal, 44(1), 81-95.

Habbershon, T. G., \& Pistrui, J. (2002). Enterprising families domain: Family-influenced ownership groups in pursuit of transgenerational wealth. Family Business Review 15(3), 223-238

Habbershon, T. G., \& Williams, M. (1999). A resource-based framework for assessing the strategic advantage of family firms. Family Business Review, 12, 1-25.

Habbershon, T. G., Williams, M., \& MacMillan, I. C. (2003). A unified systems perspective of family firm performance. Journal of Business Venturing, 18, 451-465.

Hair, J. F., Black, B., Babin, B., Anderson, R. E., \& Tatham, R. L. (2006). Multivariate data analysis (6th ed.). Prentice Hall.

Hall, A., Melin, L., \& Nordqvist, M. (2001). Entrepreneurship as radical change in the family business: Exploring the role of cultural patterns. Family Business Review 14(3), 193-208

Hofstede, G. (2001). Cultures consequences: Comparing values, behavior, institutions, and organizations across nations (2nd ed.). Thousand Oaks: Sage Publications.

Hogg, M. A., \& Terry, D. I. (2000). Social identity and selfcategorization process in organizational contexts. Academy of Management Review, 25(1), 121-140.

Hu, L. T., \& Bentler, P. M. (1995). Evaluating model fit. In R. H. Hoyle (Ed.), Structural equation modeling: Concepts, issues, and applications (pp. 76-99). Thousand Oaks, CA: Sage.

Johns, G. (2006). The essential ipmact of context on organizational behavior. Academy of Management Review, 31(2), 386-408.

Karreman, D., \& Rylander, A. (2008). Managing meaning through branding-The case of a consulting firm. Organization Studies, 29(1), 103-125. 
Kellermanns, F. W., \& Eddleston, K. (2006). Corporate venturing in family firms: Does the family matter? Entrepreneurship Theory and Practice, 30(6), 809-830.

Kellermanns, F. W., Eddleston, K., Barnett, T., \& Pearson, A. W. (2008). An exploratory study of family member characteristics and involvement: Effects on entrepreneurial behavior in the family firm. Family Business Review, 21(1), 1-14.

Kellermanns, F. W., Eddleston, K. A., Sarathy, R., \& Murphy, F. (in press). Innovativeness in family firms: A family influence perspective. Small Business Economics Journal.

Kelly, L. M., Athanassiou, N., \& Crittenden, W. F. (2000). Founder centrality and strategic behavior in the family-owned firm. Entrepreneurship: Theory and Practice, 25(2), 27-42.

Kline, R. B. (1998). Principles and practice of structural equation modeling. New York: The Guilford Press.

Kumar, N., Stern, L. W., \& Anderson, J. C. (1993). Conducting interorganizational research using key in-formants. Academy of Management Journal, 36(6), 16331651.

Le Breton-Miller, I., \& Miller, D. (2006). Why do some family businesses out-compete? Governance, long-term orientation, and sustainable capability. Entrepreneurship Theory and Practice, 30, 731-746.

Le Breton-Miller, I., Miller, D., \& Steier, L. P. (2004). Toward an integrative model of effective FOB succession. Entrepreneurship Theory and Practice, 28(4), 305-329.

Levinson, R. E. (1987). Problems in managing a family-owned business. In C. E. Aronoff \& J. L. Ward (Eds.), Family business sourcebook (pp. 169-174). Detroit: Omnigraphics, Inc.

Ling, Y., \& Kellermans, F. (2010). The effects of family firm specific sources of TMT diversity: The moderating role of information exchange frequency. Journal of Management Studies, 47(2), 322-344.

Lubatkin, M. H., Schulze, W. S., Ling, Y., \& Dino, R. N. (2005). The effects of parental altruism on the governance of family-managed firms. Journal of Organizational Behavior, 26(3), 313-330.

Lumpkin, G. T., \& Dess, G. D. (2006). The effect of 'simplicity' on the strategyperformance relationship: A note. Journal of Management Studies, 43(7), 15831604.

Lumpkin, G. T., \& Dess, G. G. (1996). Clarifying the entrepreneurial orientation construct and linking it to performance. Academy of Management Review, 21(1), 135172.

Lumpkin, G. T., \& Lichtenstein, B. B. (2005). The role of organizational learning in the opportunity recognition process. Entrepreneurship Theory and Practice, 29(4), 451472 .

Lyman, A. R. (1991). Customer service: Does family ownership make a difference? Family Business Review, 4(3), 303-324.

Mael, F. A., \& Ashforth, B. E. (1995). Loyal from day one: Biodata, organizational identification, and turnover among newcomers. Personnel Psychology, 48(2), 309-333.

Makadok, R. (2001). Toward a synthesis of the resource-based and dynamic-capability view of rent creation. Strategic Management Journal, 22, 387-401.

March, J. G., \& Shapira, Z. (1987). Managerial perspectives on risk and risk taking. Management Science, 33(11), 1404-1418.

Martins, L., \& Kellermanns, F. W. (2004). Student acceptance of a web-based course management system. Academy of Management Learning and Education, 3(1), 7-26.

Memili, E., Lumpkin, G. T., \& Dess, G. G. (2010). Entrepreneurial orientation: The driving force for corporate entrepreneurship. In P. Mazzola \& F. W. Kellermanns (Eds.), Handbook of strategy process research (pp. 326-349). Cheltenham, UK: Edward Elgar Publishing.

Miller, D., \& Friesen, P. H. (1978). Archetypes of strategy formulation. Management Science, 24(9), 921-933.

Miller, D., \& Friesen, P. H. (1982). Innovation in conservative and entrepreneurial firms: Two models of strategic momentum. Strategic Management Journal, 3, 1-25.

Miller, D., \& Le Breton-Miller, I. (2005). Managing for the long run: Lessons in competitive advantage from great family businesses. Boston, MA: Harvard Business School Press.

Miller, D., \& Le Breton-Miller, I. (2006). Priorities, practices and strategies in successful and failing family businesses: An elaboration and test of the configuration perspective. Strategic Organization, 4(4), 379-407.

Morris, M. H. (1998). Entrepreneurial intensity. Westport, CT: Quorum Books.

Mulaik, S. A., James, L. R., Alstine, J. V., Bennett, N., Ling, S., \& Stilwell, C. D. (1989). Evaluation of goodness-of-fit for structural equation models. Psychological Bulletin, 105(3), 430-445.

Nag, R., Corley, K. G., \& Gioia, D. A. (2007). The intersection of organizational identity, knowledge, and practice: Attempting strategic change via knowledge grafting. Academy of Management Journal, 50(4), 821-847.

Nahapiet, J., \& Ghoshal, S. (1998). Social capital, intellectual capital, and the organizational advantage. Academy of Management Review, 23(2), 242-266.

Naldi, L., Nordqvist, M., Sjoberg, K., \& Wiklund, J. (2007). Entrepreneurial orientation, risk taking, and performance in family firms. Family Business Review, 20(1), 33-47.

Nordqvist, M. (in press). Entrepreneurial orientation in family firms. Zeitschrift für KMU und Entrepreneurship.
Podsakoff, P. M., \& Organ, D. W. (1986). Self-reports in organizational research: Problems and perspectives. Journal of Management, 12, 531-544.

Poppo, L., \& Zenger, T. (2002). Do formal contracts and relational governance function as substitutes or complements? Strategic Management Journal, 23, 707-725.

Post, J. E. (1993). The greening of the Boston Park Plaza Hotel. Family Business Review, 6(2), 131-148.

Ravasi, D., \& Schultz, M. (2006). Responding to organizational identity threats: Exploring the role of organizational culture. Academy of Management Journal, 49(3), 433458 .

Rindova, V. P., Williamson, I. O., Petkova, A. P., \& Sever, J. M. (2005). Being good or being known: An empirical examination of the dimensions, antecedents, and consequences of organizational reputation. Academy of Management Journal, 48(6), 1033-1049.

Romano, C. A., Tanewski, G., \& Smyrnios, K. X. (2001). Capital structure decision making: A model for family business. Journal of Business Venturing 16(3), 285-310.

Sako, M. (1991). The role of trust in Japanese buyer-supplier relationships. Ricerche Economiche, XLV, 449-474.

Schulze, W. S., Lubatkin, M. H., \& Dino, R. N. (2003). Exploring the agency consequences of ownership dispersion among the directors of private family firms. Academy of Management Journal, 46(2), 179-194.

Schulze, W. S., Lubatkin, M. H., Dino, R. N., \& Buchholtz, A. K. (2001). Agency relationships in family firms: Theory and evidence. Organization Science, 12(2), 99-116.

Scott, S. G., \& Lane, V. R. (2000). A stakeholder approach to organizational identity. Academy of Management Review, 25(1), 43-62.

Seidler, J. (1974). On using key informants: A technique for collecting quantitative data and controlling measurement error in organization analysis. American Sociological Review, 39, 816-831.

Shapira, Z. (1995). Risk taking: A managerial perspective. New York: Russel Sage Foundation.

Simonin, B. L. (1997). The importance of collaborative know-how: An empirical test of the learning organization. Academy of Management Journal, 40, 1150-1174.

Singh, J. V. (1986). Performance, slack, and risk taking in organizational decision making. Academy of Management Journal, 29(3), 562-585.

Sirmon, D. G., \& Hitt, M. A. (2003). Managing resources: Linking unique resources, management and wealth creation in family firms. Entrepreneurship Theory and Practice, 27(4), 339-358.

Smidts, A., Pruyn, A. H., \& Van Riel, C. B. M. (2001). The impact of employee communication and perceived external prestige on organizational identification. Academy of Management Journal, 49(5), 1051-1062.

Spector, P. E. (2006). Method variance in organizational research: Truth or urban legend. Organizational Research Methods, 9(2), 221-232.

Steier, L. (2001). Next-generation entrepreneurs and succession: An exploratory study of modes and means of managing social capital. Family Business Review, 14(3), 339358

Straub, D., Limayem, M., \& Karahanna-Evaristo, E. (1995). Measuring system usage: Implications for theory testing. Management Science, 41(8), 1328-1342.

Sundaramurthy, C., \& Kreiner, G. E. (2008). Governing by managing identity boundaries: The case of family businesses. Entrepreneurship Theory and Practice, 32(3), 415-436.

Tagiuri, R., \& Davis, J. A. (1996). Bivalent attributes of the family firm. Family Business Review, 9(2), 199-208

Teece, D. J., Pisano, G., \& Shuen, A. (1997). Dynamic capabilities and strategic management. Strategic Management Journal, 18(7), 509-533.

Uhlaner, L. M., Kellermanns, F. W.. Eddleston, K. A., \& Hoy, F. (in press). The entrepreneuring family: It is time for a new paradigm? Small Business Economics Journal.

Volery, T., Bergmann, H., Gruber, M., Haour, G., \& Leleux, B. (2007). Global Entrepreneurship monitor-Swiss report. St. Gallen: University of St. Gallen.

Ward, J., \& Aronoff, C. E. (1995). Family-owned businesses: A thing of the past or a model for the future. Family Business Review, 8(2), 121-130.

Ward, J. L. (1997). Growing the family business: Special challenges and best practices. Family Business Review, 10, 323-337.

Ward, J. L., \& Aronoff, C. E. (1991). Trust gives you the advantage. Nation's Business, 79(8), 42-44.

Weigelt, K., \& Camerer, C. (1988). Reputation and corporate strategy: A review of recent theory and applications. Strategic Management Journal, 9(5), 443-454.

Whetten, D. A., \& Mackey, A. 2005. An identity-congruence explanation of why firms would consistently engage in corporate social performance. Working paper. Provo, UT: Brigham Young University.

Wilken, P. H. (1979). Entrepreneurship: A comparative and historical study. Norwood, NJ: ABLEX Publishing Corporation.

Zahra, S. A. (2003). International expansion of US manufacturing family businesses: The effect of ownership and involvement. Journal of Business Venturing, 19, 495512

Zahra, S. A. (2005). Entrepreneurial risk taking in family firms. Family Business Review, 18(1), 23-40. 